\title{
The Internal Organs Weight of 6-Weeks Old Native Chickens after L-threonine and L-tryptophan Supplement in Feed
}

\author{
Charles Venirius Lisnahan* and Oktovianus Rafael Nahak \\ Agricultural Faculty, Timor University, Kefamenanu - Nusa Tenggara Timur, Indonesia \\ *Corresponding author email: charleslisnahan@yahoo.co.id
}

\begin{abstract}
The aim of this experiment was to identify the internal organs weight of 6-weeks old native chickens after treatment feed with I-threonine and I-tryptophan supplement. This experimental research used 128 native chickens aged one-week-old in a Completely Randomized Design with four treatments and four replications. The dietary treatments were T0 (control feed), T1 (T0 + 0.35\% I-threonine $+0.10 \%$ I-tryptophan), T2 (T0 + 0.68\% I-threonine + 0.17\% I-tryptophan), and T3 (T0 + 1.00\% I-threonine + 0.25\% I-tryptophan). The variables measured included body weight, liver weight, pancreas weight, gizzard weight, and intestinal length. Statistical analysis showed that I-threonine and I-tryptophan significantly affected body weight, liver weight, pancreas weight, gizzard weight and intestinal length. Supplementing $1.00 \%$ I-threonine and $0.25 \% \quad$ tryptophan to feed contributed to the highest body weight and internal organs weight of native chickens.
\end{abstract}

Keywords: native chicken, I-threonine, I-tryptophan, internal organs

Abstrak. Penelitian ini bertujuan mengetahui berat organ dalam ayam kampung berumur 6 minggu setelah disupplementasi I-treonin dan I-triptofan dalam pakan. Sebanyak 128 ekor ayam kampung berumur 1 minggu digunakan dalam penelitian ini. Penelitian ini dirancang menggunakan Rancangan Acak Lengkap terdiri dari 4 perlakuan dan 4 ulangan. Perlakuan yang diberikan adalah T0 (pakan kontrol tanpa suplementasi I-treonin dan I-triptofan); T1 (suplemetasi 0,35\% I-treonin dan 0,10\% I-triptofan); T2 (suplementasi 0,68\% I-treonin dan 0,17\% I-triptofan); dan T3 (suplementasi 1,00\% I-treonin dan 0,25\% I-triptofan). Data yang dikoleksi adalah berat badan, berat liver, berat pankreas, berat gizzard dan panjang usus. Uji statistika menunjukkan bahwa suplementasi I-treonin dan I-triptofan berpengaruh signifikan terhadap berat badan, berat hati, berat pankreas, berat gizzard dan panjang usus ayam kampung. Disimpulkan bahwa suplementasi 1,00\% I-treonin dan 0,25\% I-triptofan memberikan berat badan dan berat organ dalam tertinggi ayam kampung.

Kata kunci: ayam kampung, I-treonin, I-triptofan, organ dalam

\section{Introduction}

Native chicken is one of low-maintenance and compact-bodied livestock that produce meat and egg. The most important thing to consider in increasing the production and reproduction is the feed factor. Previous studies have not obtained a complete result on nutrient requirements particularly the micro-nutrient balance; however, an experiment supplementing $0.30 \%$ methionine and $0.85 \%$ lysine to starter chicken reported 2,957.91 kcal $\mathrm{kg}^{-1}$ ME metabolizable energy (ME), $16.77 \%$ crude protein, $1.62 \%$ calcium, and $0.58 \%$ phosphorus (Lisnahan et al., 2017). The production of native chickens can be increased by other limiting amino acids such as threonine and tryptophan. Min et al. (2017) and Chen et al. (2017) reported that broiler chickens given $0.75 \%$ threonine exhibited an optimized body weight and feed efficiency. Also, tryptophan affected regulate feed intake and behavior, growth, immunity, protein synthesis and intestinal integrity of livestock (Shen et al., 2012; Wen et al., 2014).

Threonine and tryptophan are limiting amino acids after methionine and lysine. Threonine contributes to bone formation, fat metabolism and digestive function; controls the body's health and immune system, liver and nerves and maintains body protein (Qaisrani et al., 2018). Tryptophan, as reported by Iwuji et al. (2014) and Hoseini et al. (2019), triggers the production of serotonin, stimulates niacin production, increases appetite and feed 
efficiency, stimulates growth, and increases body weight. The production of meat and eggs in the grower, pullet and layer phases is largely determined by growth in the starter phase. To date, the threonine and tryptophan standard requirements for native chickens in the starter phase has not been established compared to broilers and laying hens. Supplementing the two amino acids in feed could improve the complete micro-nutrient composition. A balanced nutrition offered to native chicken at starter phase (1-6 weeks) would optimize the growth.

\section{Materials and Methods}

This research was conducted in Kefamenanu City, East Nusa Tenggara Province, Indonesia from February to March 2019. A total of 128 day-old native chicks were randomly allotted to 16 cage units in a Completely Randomized Design (CRD) with four treatments and four replications. The treatments were T0 (control feed), T1 (TO + 0.35\% l-threonine $+0.10 \%$ Itryptophan), $\mathrm{T} 2$ (T0 $+0.68 \%$ I-threonine $+0.17 \%$ I-tryptophan), and T3 (T0 + 1.00\% I-threonine + $0.25 \%$ I-tryptophan). The feed ingredients and nutrient composition of each treatment are presented in Table 1. The variables observed were body weight, liver, pancreatic, gizzard, small intestine, and intestinal length. The data obtained were subjected to analysis of variance based on CRD and Duncan's test.

\section{Results and Discussion \\ Body Weight}

The average body weight of native chickens on the starter phase (DOC to 6 weeks) is presented in Table 2 . The highest average body weight was observed in $\mathrm{T} 3$, followed by $\mathrm{T} 2, \mathrm{~T} 1$, and TO. Statistical analysis showed that the treatments significantly affected body weight $(p<0.01)$.

Table 1. Composition (\%) and nutrient content (\%DM) of experiment diets during the starter phase

\begin{tabular}{|c|c|c|c|c|}
\hline \multirow{2}{*}{ Ingredients } & \multicolumn{4}{|c|}{ Treatments (\%) } \\
\hline & T0 & $\mathrm{T} 1$ & $\mathrm{~T} 2$ & $\mathrm{T3}$ \\
\hline Yellow corn & 50.10 & 50.10 & 50.10 & 50.10 \\
\hline Rice bran & 33.10 & 32.65 & 32.25 & 31.85 \\
\hline Soybean meal & 8.00 & 8.00 & 8.00 & 8.00 \\
\hline Fish meal & 7.00 & 7.00 & 7.00 & 7.00 \\
\hline Limestone & 0.32 & 0.32 & 0.32 & 0.32 \\
\hline Vitamin premix & 0.42 & 0.42 & 0.42 & 0.42 \\
\hline DL-methionine & 0.27 & 0.27 & 0.27 & 0.27 \\
\hline L-lysine $\mathrm{HCl}$ & 0.79 & 0.79 & 0.79 & 0.79 \\
\hline L-Threonine & 0 & 0.35 & 0.68 & 1.00 \\
\hline L-Tryptophan & 0 & 0.10 & 0.17 & 0.25 \\
\hline Total & 100.00 & 100.00 & 100.00 & 100.00 \\
\hline \multicolumn{5}{|l|}{ Calculated nutrients } \\
\hline Metabolized energy $\left(\mathrm{kcal} \mathrm{kg}^{-1}\right)$ & $2,957.91$ & $2,947.89$ & $2,938.97$ & $1,930.06$ \\
\hline Crude protein (\%) & 16.77 & 16.72 & 16.67 & 16.63 \\
\hline Ether extract (\%) & 6.01 & 5.97 & 5.94 & 5.90 \\
\hline Ash (\%) & 8.08 & 8.04 & 8.00 & 7.96 \\
\hline Crude fiber (\%) & 6.97 & 6.91 & 6.85 & 6.79 \\
\hline Methionine (\%) & 0.30 & 0.30 & 0.30 & 0.30 \\
\hline Lysine (\%) & 0.85 & 0.85 & 0.85 & 0.85 \\
\hline Threonine (\%) & 0.05 & 0.40 & 0.72 & 1.05 \\
\hline Tryptophan (\%) & 0.03 & 0.13 & 0.20 & 0.28 \\
\hline Calcium (\%) & 1.62 & 1.62 & 1.62 & 1.62 \\
\hline Phosphorus (\%) & 0.58 & 0.58 & 0.58 & 0.58 \\
\hline
\end{tabular}


Charles Venirius Lisnahan et al./Animal Production. 21(2):81-86, 2019

Accredited by Kemenristek Dikti No 32a/E/KPT/2017. ISSN 1411-2027

Table 2. Performance of native chickens fed different diets during the starter phase ( $1-6$ weeks of age)

\begin{tabular}{lllll}
\hline \multirow{2}{*}{ Parameters } & \multicolumn{4}{c}{ Treatments } \\
\cline { 2 - 5 } & T0 & T1 & T2 & T3 \\
\hline Body weight (g/bird) & $286.43 \pm 6.97^{\mathrm{d}}$ & $302.87 \pm 8.75^{\mathrm{c}}$ & $320.37 \pm 4,37^{\mathrm{b}}$ & $330,29 \pm 3.73^{\mathrm{a}}$ \\
Liver (g/bird) & $8.21 \pm 0.39^{\mathrm{d}}$ & $9.25 \pm 0.32^{\mathrm{c}}$ & $9.95 \pm 0.20^{\mathrm{b}}$ & $11.11 \pm 0.46^{\mathrm{a}}$ \\
Liver (\%/bird) & $2.87 \pm 0.15^{\mathrm{c}}$ & $3.05 \pm 0.02^{\mathrm{b}}$ & $3.11 \pm 0.03^{\mathrm{b}}$ & $3.36 \pm 0.15^{\mathrm{a}}$ \\
Pancreas (g/bird) & $0.59 \pm 0.02^{\mathrm{bc}}$ & $0.60 \pm 0.03^{\mathrm{b}}$ & $0.65 \pm 0.02^{\mathrm{ab}}$ & $0.68 \pm 0.06^{\mathrm{a}}$ \\
Pancreas (\%/bird) & $0.21 \pm 0.01$ & $0.20 \pm 0.01$ & $0.20 \pm 0.01$ & $0.21 \pm 0.02$ \\
Gizzard (g/bird) & $6.42 \pm 0.33^{\mathrm{c}}$ & $6.96 \pm 0.13^{\mathrm{b}}$ & $7.12 \pm 0.19^{\mathrm{ab}}$ & $7.41 \pm 0.14^{\mathrm{a}}$ \\
Gizzard (\%/bird) & $2.24 \pm 0.08^{\mathrm{b}}$ & $2.30 \pm 0.03^{\mathrm{b}}$ & $2.22 \pm 0.05^{\mathrm{a}}$ & $2.24 \pm 0.06^{\mathrm{a}}$ \\
Intestine length (cm/bird) & $55.60 \pm 1.63^{\mathrm{c}}$ & $57.40 \pm 0.86^{\mathrm{bc}}$ & $60.65 \pm 1.42^{\mathrm{b}}$ & $65.75 \pm 2.47^{\mathrm{a}}$ \\
Small intestine weight & $11.81 \pm 0.86^{\mathrm{b}}$ & $12.58 \pm 0.71^{\mathrm{b}}$ & $13.41 \pm 0.65^{\mathrm{ab}}$ & $13.91 \pm 0.99^{\mathrm{a}}$ \\
(g/bird) & & & & \\
Small intestine (\%/bird) & $4.12 \pm 0.24^{\mathrm{b}}$ & $4.16 \pm 0.34^{\mathrm{b}}$ & $4.19 \pm 0.22^{\mathrm{ab}}$ & $4.21 \pm 0.34^{\mathrm{a}}$ \\
\hline a,b,c,d, & & & &
\end{tabular}

${ }_{a, b, c, d}$ Different superscript on the same line indicates significant difference $(p<0.05)$

Supplementation of $0.35 \%$ I-threonine + $0.10 \%$ I-tryptophan increased body weight by $5.74 \%$. When the supplement was improved to $0.68 \%$ I-threonine $+0.17 \%$ I-tryptophan in feed, body weight increased by $11.85 \%$. The supplementation of $1.00 \%$ I-threonine $+0.25 \%$ I-tryptophan produced the highest body weight ( $330.29 \mathrm{~g} / \mathrm{bird}$ ) which was $15.31 \%$ higher of the control group. This result supported Lisnahan et al. (2017) that the body weight of 6 weeks-old native chickens supplemented with dlmethionine and I-lysine $\mathrm{HCL}$ (without Ithreonine and I-tryptophan) was $284.61 \mathrm{~g} / \mathrm{bird}$. For chicken, threonine and tryptophan are the third critical amino acids after methionine and lysine (Qaisrani et al., 2018). Threonine affects feed intake and body weight (Estalkhzir et al. 2013), while tryptophan contributes to protein biosynthesis, builds muscle mass and stimulates immune responses, enhances the immune system, maintains internal proteins, induces growth and increases antibodies, and acts as serotonin precursors and control aggressiveness (Younis et al., 2016; Hoseini et al., 2019). Supplementation of $0.23-0.31 \%$ tryptophan in feed was reported to increase broilers' weight (Opoola, 2017).

\section{Liver}

The average liver weight was affected by levels of I-threonine and I-tryptophan $(p<0.01)$. The highest liver weight ( $11.11 \mathrm{~g} / \mathrm{bird}$ or $3.36 \%)$ was on $1.00 \%$ I-threonine $+0.25 \%$ I-tryptophan supplement. Liver weight increased by $12.67 \%$ with $0.35 \%$ I-threonine $+0.10 \%$ I-tryptophan supplement, and by $7.57 \%$ with $0.68 \%$ Ithreonine and $0.17 \%$ I-tryptophan. At T3, the percentage of liver weight increased by $11.66 \%$ from $\mathrm{T} 2$.

Liver weight correlates with the body weight of native chickens. As I-threonine and Itryptophan supplement increased body weight, the size of organs (including liver) also increased. The liver is the house for fat emulsions and gallbladder link. In digestion, liver is important to produce bile sap which is channeled into the duodenum (NRC, 2000; Scanes et al., 2004). Feed that enters the duodenum stimulates the gallbladder to shrink and expel bile sap into the duodenum, which can help absorb fat by the small intestine (Pesti et al., 2005). Percentage of the liver as was reported by Younis et al. (2016) reported that liver percentage increased when given $0.2 \%$ tryptophan in feed. Also, liver percentage 
increased with the addition of threonine levels in 42-days-old broilers (Estalkhzir et al., 2013). The average weight of the liver and gall of native chicken was $5.56 \%$ of body weight (Lisnahan et al. 2017).

\section{Gizzard}

The gizzard weight was affected by different levels of I-threonine and I-tryptophan $(p<0.01)$. Supplementing $0.35 \%$ I-threonine $+0.10 \%$ I tryptophan increased the gizzard weight by $8.41 \%$. When I-threonine and I-tryptophan were increased to 0.68 and $0.17 \%$ in the feed, the gizzard weight increased by $2.30 \%$. At the level of $1.00 \%$ I-threonine and $0.25 \%$ I-tryptophan, the gizzard weight still increased by $4.07 \%$. It showed that the percentage of gizzard weight also increased $(2.24-2.42)$ with different levels of I-threonine and I-tryptophan supplement $(p<0.05)$. The gizzard weight of native chicken was highest $(7.41 \mathrm{~g} / \mathrm{bird})$ in feed supplemented with $1.00 \%$ I-threonine $+0.25 \%$ I-tryptophan.

The gizzard is the mechanical stomach in the digestive tract. The consumed feed and digestive juices from the salivary glands and the proventriculus pass into the gizzard (Svihus, 2014) where the feed was ground, mixed and mashed. The gizzard weight correlates with the body weight of the native chicken; the bigger the gizzard, the bigger kaolin surface area to grind feed. Supplementation of threonine and tryptophan in the feed required a more balanced essential amino acids, and a balanced nutrition impacts better growth, including gizzard.

\section{Small Intestine}

The weight of the small intestine was affected by different levels of I-threonine and Itryptophan $(p<0.05)$. Supplementing $0.35 \%$ Ithreonine $+0.10 \%$ I tryptophan did not affect the weight of the small intestine. However, $0.68 \%$ I-threonine $+0.17 \%$ I-tryptophan increased small intestine weight by $13.55 \%$, and $1.00 \%$ I-threonine $+0.25 \%$ I-tryptophan produced the highest intestine weight, i.e. $13.91 \mathrm{~g} / \mathrm{bird}$ which was or $17.78 \%$ bigger than the control group. The increase in small intestine weight was followed by the percentage increase $(p<0.05)$ from 4.12 to 4.21 . Furthermore, different levels of I-threonine and I-tryptophan also affected intestine length. The longest intestines $(65.75 \mathrm{~cm} /$ bird) was observed in $1.00 \%$ I-threonine $+0.25 \%$ I-tryptophan, or $18.28 \%$ longer than the control group. However, supplementing $0.68 \%$ I-threonine + $0.17 \%$ I tryptophan only increased intestinal length by $9.08 \%$.

The intestinal weight and length correlate with chicken body weight. The intestine is a major part of the digestion of feed and absorption of nutrients (Svihus, 2014); the longer and heavier the intestines, the more feed to be digested and absorbed. The balanced amino acids, especially essential amino acids, build better body tissues and support better growth and chicken intestine. Threonine functions are to regulate protein balance and amino acids, maintain intestinal function and improve immune responses (Chen et al., 2017; Al-Hayani, 2017; Qaisrani et al., 2018). Lthreonine and I-tryptophan are directly absorbed by the intestine; however, Wang et al. (2007) stated that threonine deficiency or excess reduced the synthesis of mucus proteins and muscle proteins in young pigs. Previous study reported a significant effect of crude protein and threonine on the weight relative and the length of the duodenum and jejunum of broilers (Zaghari et al., 2011).

\section{Pancreas}

The pancreatic weight was affected by different levels of I-threonine and I-tryptophan $(p<0.05)$. Addition of I-threonine and Itryptophan to $1.00 \%$ and $0.25 \%$, increased pancreatic weight by $15.25 \%$. Previous study reported that the pancreas percentage of native chickens was $0.39 \%$ (Lisnahan, 2018). The pancreas correlates with chicken body 
weight, and pancreas size reflects the amount of trypsin, lipase and amylase secretion. The pancreas consists of 2 parts, the $\alpha$-pancreas which produces protease, lipase and amylase enzymes, and $\beta$-pancreas which produces insulin. Also, pancreas secretes trypsin which digests protein. The supplement of I-threonine and I-tryptophan in feed has balanced the essential amino acid composition. L-threonine and I-tryptophan are directly absorbed by the intestine and form the body tissues including the pancreas. The poultry feed contains proteins fortified with synthetic amino acids that potentially enlarge the pancreas (Feng et al. 2017). Pancreas takes up $0.28 \%$ of broilers' body weight (Palaniyandi et al., 2018).

\section{Conclusion}

Supplementation of I-threonine and Itryptophan in feed increased native chickens' body and visceral gizzard, liver, pancreas, and small intestine of the native chickens aged 1-6 weeks. Levels of $1.00 \%$ I-threonine and $0.25 \%$ Itryptophan give the best results.

\section{Acknowledgments}

The authors thank Direktorat Jenderal Penguatan Riset dan Pengembangan Kementerian Riset, Teknologi dan Pendidikan Tinggi for the research grant "Hibah Penelitian Dasar".

\section{References}

Al-Hayani W. A. 2017. Effect Of Threonine Supplementation On Broiler Chicken Productivity Traits. International Journal of Poultry Science. 16(4):160-168.

Chen, Y. P., Y. F. Cheng, X. H. Li, W. L. Yang, C. Wen, S. Zhuang and Y. M. Zhou. 2017. Effects Of Threonine Supplementation On The Growth Performance, Immunity, Oxidative Status, Intestinal Integrity And Barrier Function of Broilers At The Early Age. Poultry Science. 96:405-413.

Estalkhzir, F. M., S. Khojasteh and M. Jafary. 2013. The Effect Of Different Levels Of Threonine On Performance And Carcass Characteristics of
Broiler Chickens. Journal Nov. Appl. Science. 2(9):382-386.

Feng, L., X. Liu, R. Xu, Y. Z. Wang and J. X. Liu. 2007. Effects Of Fermented Soybean Meal On Digestive Enzyme Activities And Intestinal Morphology In Broiler. Journal Poultry Science. 86:1149-1154.

Hoseini, S. M., A. P. Jimenez, B. Costas, R. Azeredo and M. Gesto. 2019. Physiological Roles In Teleosts: Current Knowledge And Perspectives For Future Studies. Rev. Aquacult. 11: 3-24.

Iwuji, T. C., A. H. Akinmutimi, I. P. Ogbuewu, I. F. Etuk and V. U. Odoemelam. 2014. Roles Of Tryptophan In Monogastric Nutrition: A Review. Advances in Agriculture, Science and Engineering Research. 4(3):1544-1556.

Lisnahan, C. V., Wihandoyo, Zuprizal and S. Harimurti. 2017. Effect of Addition Of Methionine And Lysine Into Diets Based On Cafeteria Standards On The Growth Performance Of Native Chickens At Starter Phase. International Journal of Poultry Science. 16(12):506-510.

Lisnahan, C. V. 2018. Penentuan Kebutuhan Nutrien Ayam Kampung Fase Pertumbuhan Yang Dipelihara Secara Intensif Dengan Metode Kafetaria. Disertasi, Fakultas Peternakan, Universitas Gadjah Mada, Yogyakarta.

Min, Y. N., S. G. Liu, Z. X. Qu, G. H. Meng and Y. P. Gao. 2017. Effects Of Dietary Threonine Levels On Growth Performance, Serum Biochemical Indexes, Antioxidant Capacities And Gut Morphology In Broiler Chickens. Poultry Science. 96(5):1290-1297.

NRC (National Research Council). 2000. Nutrient Requairement of Poultry Eight Revised Ed. National Academy Press, Washington, DC 155 pages.

Opoola, E., P. A. Onimisi, S. O. Ogundipe and G. S. Bawa. 2017. Efffect Of Dietary Tryptophan Levels On Growth Performance Of Broiler Chickens Reared In The Hot Season Under Tropical Environment. Tropical and Subtropical Agroecosystems. 20:429-437.

Palaniyandi, K., B. Mannu, R. Shunmugan, R. Sambandam and S. S. Harishchandra. 2018. Effect of in-ovo injection of glucose, lysine, threonine and $\beta$-hydroxy- $\beta$-methylburate (HMB) on the morphometry of digestive organs in commercial broilers. International Journal of Livestock Research. 8(9):177-183.

Pesti, G. M., R. I. Bakalli, J. P. Driver, A. Atencio and E. H. Foster. 2005. Poultry Nutrition and Feeding. The University of Georgia. Department of Poultry Science, Trafford Publishing, Athens.

Qaisrani, S. N., I. Ahmed, F. Azam, F. Bibi, Saima, T. N. Pasha and F. Azam. 2018. Threonine in broiler 
diets: an updated review. Annal Animal Science. 18(3):659-674.

Scanes, C. G., G. Brant and M. E. Ensminger. 2004. Poultry Science. Upper Saddle River, New Jersey, USA, Pearson Prentice Hall 512 pages.

Shen, Y. B., G. Voilque, J. D. Kim, J. Odle and S. W. Kim. 2012. Effects Of Increasing Tryptophan Intake On Growth And Physiological Changes In Nursery Pigs. Journal of Animal Science. 90(7):2264-2275.

Svihus, B. 2014. Function Of The Digestive System. Journal Applied Poultry Research. 23(2):306-314.

Wen, H., L. Feng, W. Jiang, Y. Liu, J. Jiang, S. Li, L. Tang, Y. Zhang, S. Kuang and X. Zhou. 2014. Dietary Tryptophan Modulates Intestinal Immune Response, Barrier Function, AntiOxidant Status And Gene Expression Of TOR And Nrt2 In Young Grass Carp (Ctenopharyngodon idella). Fish Shellfish Immun. 40(1):275-287.

Wang, X., S. Y. Qiao, Y. L. Yin, L. Y. Yue, Z. Y. Wang and G. A. Wu. 2007. Defisiensy Or Excess Of Dietary Threonine Reduces Protein Synthesis In Jejunum And Skeletal Muscle Of Young Pigs. Journal of Nutrition. 137:1442-1446.

Younis, M. E., M. A. El-Edel, S. M. Nasr, U. E. Mahrous and M. M. Aboghanima. 2016. Response Of Cobb And Sasso Broilers To Feeding Restriction And Tryptophan Supplementation. Alexandria Journal of Veterinary Science. 51(1): 127-134.

Zaghari, M., F. Zaefarian and M. Shivazad. 2011. Standardized Ileal Digestible Threonine Requirements And Its Effects On Performance And Gut Morphology Of Broiler Chicks Fed Two Levels Of Protein. Journal of Agricultural Science and Technology. 13:541-552. 